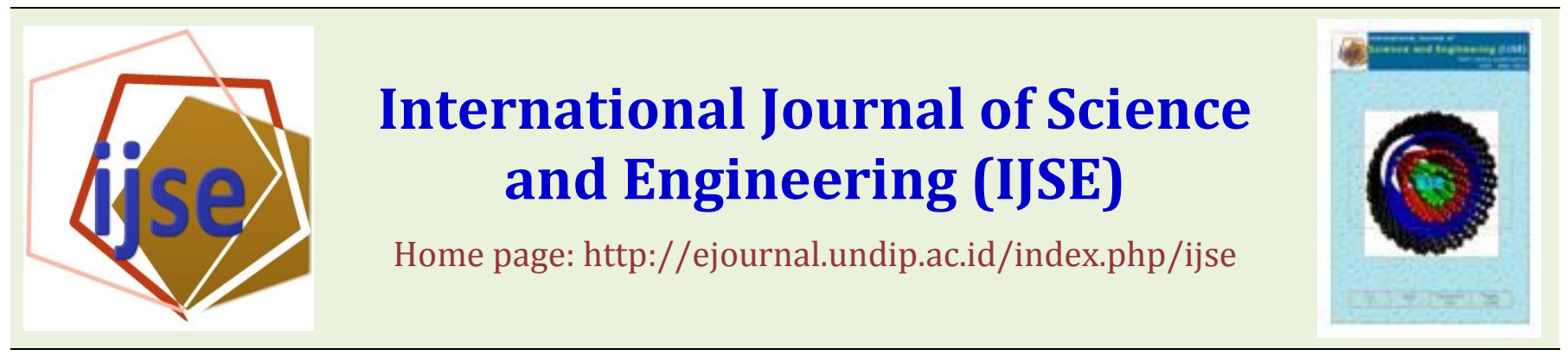

\title{
Intake and Digestibility of Cattle's Ration on Complete Feed Based-On Fermented Ammonization Rice Straw with Different Protein Level
}

\author{
Hamdi Mayulu'1), Sunarso ${ }^{2)}$, M. Christiyanto ${ }^{2)}$ and F. Ballo ${ }^{3)}$ \\ Email: mayoeloehsptno@yahoo.com \\ 1)Mulawarman University,Kampus Gunung Kelua Jl.Kuaro Samarinda, Indonesia \\ 2)Diponegoro University, Kampus drh.Soejono Koesoemowardoyo Semarang Indonesia \\ 3)SPPN Kupang, Jl.Timor Raya Km 39 Lili Kupang Indonesia
}

\begin{abstract}
Complete feed (CF) utilization is expected to have impact on higher productivity due to increased intake and digestibility. The objective of research was to evaluate the effects of different level protein of CF based-on fermented ammonization (amofer) rice straw to Simmental offspring intake and digestibility Twenty males Simmental offspring with average live weight $372.15 \pm 26.64 \mathrm{~kg}$ (coefficient of variance 7.16\%) were used in this study. Feed treatment consisted of BC Nutrifeed 132 concentrate as control feed (To) and $C F$ based-on amofer rice straw consisted of $T_{1}, T_{2}, T_{3}$ and $T_{4}$ which had crude protein content $11,12,13$ and $14 \%$ respectively and also total digestible nutrients (TDN) $\pm 62 \%$. Completely randomized design with five treatments and four replicates were designed for this research. Data was analyzed by analysis of variance (ANOVA) at 95\% significance level. The results showed that different crude protein did not affect the intake of dry matter, organic matter, crude protein and TDN. It was significantly affected the digestibility of dry matter, organic matter and crude protein $(p<0.01)$. The highest digestibility was obtained to treatment with $12 \%$ crude protein and $\pm 62 \%$ TDN. Conclusion of this study was different level of crude protein constituted in CF which produced from specific material resource was proven to have impact in increasing cattle's digestibility.
\end{abstract}

Keywords - complete feed; fermented ammonization rice straw; intake; digestibility; cattle

Submission: February 10, $2012 \quad$ Corrected : March 13, 2013

Accepted: March 29, 2013

Doi: $10.12777 /$ ijse.4.2.2013.86-91

[How to cite this article: Mayulu, H., Sunarso, S., Christiyanto, M. and Ballo, F. (2013). Intake and Digestibility of Cattle's Ration On Complete Feed Based-On Fermented Ammonization Rice Straw With Different Protein Level. International Journal of Science and Engineering, 4(2),86-91. Doi: $10.12777 /$ ijse.4.2.2013.86-91]

\section{INTRODUCTION}

Livestock development especially for beef cattle breeding needs to be done through sustained effort, modern and professional by utilizing technological innovation to improve its business efficiency. The successful development of beef cattle is determined by the sufficient of food both in quantity and quality. Forage as major component of feed is derived from grazing land and other sources. Moreover, the development of beef cattle should be supported by industry which optimizes the utilization of local resources through an integrated pattern. That condition reflects the importance of crops and cattle integration. By product produced from plantation and crop could be source for livestock ration by improving their nutritional ingredients (Mathius and Sinurat, 2001;
Nkrumah et al., 2006; Diwyanto, 2008; Mathius, 2008; Muyulu et al., 2010; Kuswandi, 2011).

Ration technology is growing year to year such as complete feed (CF) for beef cattle. Complete feed provides sufficient nutrients for beef cattle in certain physiological level. CF is fed for beef cattle as the only feed which enables to meet the basic needs of life and production without the addition of other materials except water. The use of CF in beef cattle breeding can produce high productivity, so it is believed that the use of $\mathrm{CF}$ will give more efficiency both technically and economically (Hartadi et al., 1997; Mayulu, et al., 2009; Sunarso et al., 2011; Mayulu et al., 2012).

Rice straw is by-product of paddy plant which has potential source for fiber needs of beef cattle. Utilization of 
rice straw as ruminant feed has several constraints due to, a) low crude protein content; b) high content of crude fiber; c) high content of lignin; d) high content of silica; e) low carotene; and f) low digestibility. Fermented ammonization (amofer) on rice straw can increase crude protein content from 4.3 to $9.03 \%$, increase the digestibility and also preserve the feed ingredients (Prihartini, 1998; Hadi and Ilham, 2002; Suharto, 2004; Utomo, 2004). In this study, utilization of amofer rice straw as basal constituent for CF is an effort to increase efficiency by reducing feed provision cost. Beef cattle breeding either in small or industry breeding could use amofer rice straw on their ration need.

Biosynthesis of rumen microbes can work well and experience the peak performance at $5 \mathrm{mg}$ rumen ammonia /100 ml rumen fluid concentration (Satter and Slyter, 1974). The concentration is produced by ration with crude protein level between 11.4 and $13.3 \%$ at 60 to $80 \%$ TDN (Satter and Roffler, 1981). Increased level of crude protein can affect the feed intake and efficiency (Cullison and Lowrey, 1987; Basuki, 2000).

Utilization of amofer rice straw and concentrate technology with crude protein level from 10 to $14 \%$ in beef cattle breeding is proven could increase average live weight and feed efficiency (Sunarso, 2003; Mayulu et al., 2009; Sunarso et al., 2011). According to this, the research is conducted to evaluate the effect of different level of protein used in CF-based amofer rice straw on Simmental beef cattle crossbred's intake and digestibility.

\section{MATERIAL AND METHOD}

The research was conducted in Mixed Farming which locates on Agriculture Information and Extension Center, Cepu $5^{\text {th }} \mathrm{km}$, Jepon sub district, Blora district. Twenty Simmental offspring with average live body weight $372.15 \pm 26.64 \mathrm{~kg}$ (coefficient of variance $7.16 \%$ ) were used in this study. Control treatment $\left(\mathrm{T}_{0}\right)$ was of amofer rice straw mixed with $\mathrm{BC} 132$ Nutrifeed, Klaten at 5 $\mathrm{kg} /$ day. Four treatments consisted of $\mathrm{T}_{1}, \mathrm{~T}_{2}, \mathrm{~T}_{3}$ and $\mathrm{T}_{4}$ were used which had crude protein content 11, 12, 13 and 14\% respectively and also total digestible nutrients (TDN) \pm $62 \%$. The balance of amofer rice straw and concentrate were 40:60\%. CF material consisted of: amofer rice straw, yellow corn, dried cassava waste pulp, rice bran, cotton seed oil cake, coffee pulp, palm oil, palm oil cake, urea, mineral mix and salt. Feed composition and nutrient is shown in Table 1.

The beef cattle were housed in metabolic individual cages $1.25 \times 2 \mathrm{~m}$, feed were offered with feeding box while drinking water were offered using water bucket $10 \mathrm{~L}$. Research equipments used in this research were as follows: electric weighing scale "Great Scale Weighting Indicaro" type XK3190-A7 capacity $2000 \pm 1 \mathrm{~kg}$ for weighing the cattle; hanging weighing scale capacity $50 \pm 0.5 \mathrm{~kg}$ and settle weighing scale "Eva Collection" capacity $5 \pm 0.02 \mathrm{~kg}$ for weighing the CF feedstuff, offered feeding, discharged feed intake and fesses; mixer for mixing feeding material; and diesel machine.

Completely randomized design with five treatments and four replication was adopted in this research. Each replication was consisted of five male cattle. It means that twenty male cattle were used for this research. The treatment was as follows: $\mathrm{T}_{0}$ : amofer rice straw (offered $\mathrm{ad}$ libitum) and concentrate $5 \mathrm{~kg} /$ cattle/day; $\mathrm{T}_{1}$ : $\mathrm{CF}$ with crude protein $11 \%$; $\mathrm{T}_{2}$ : $\mathrm{CF}$ with crude protein $12 \% ; \mathrm{T}_{3}$ : $\mathrm{CF}$ with crude protein 13\%; and $\mathrm{T}_{4}$ : CF with crude protein $14 \%$.

Table 1. Feed material composition and nutrient content based on dry matter

\begin{tabular}{|c|c|c|c|c|c|}
\hline \multirow[t]{2}{*}{ Composition } & \multicolumn{5}{|c|}{ Treatment $(\%)$} \\
\hline & $\mathrm{T}_{0}$ & $T_{1}$ & $\mathrm{~T}_{2}$ & $\mathrm{~T}_{3}$ & $\mathrm{~T}_{4}$ \\
\hline \multicolumn{6}{|l|}{ Feedstuff: } \\
\hline Amofer rice straw & 63.37 & 40.00 & 40.00 & 40.00 & 40.00 \\
\hline Rice bran & - & 6.70 & 6.20 & 9.30 & 5.80 \\
\hline Milled corn & - & 10.00 & 10.00 & 10.00 & 10.00 \\
\hline Coffee pulp & - & 1.50 & 1.00 & 1.00 & 1.00 \\
\hline Dried cassava waste pulp & - & 30.00 & 27.00 & 21.00 & 20.00 \\
\hline Cotton seed oilcake & - & 1.00 & 3.00 & 4.50 & 8.00 \\
\hline Palm oil cake & - & 10,00 & 12.00 & 13.40 & 14.40 \\
\hline Palm oil & - & 0.10 & 0.10 & 0.10 & 0.10 \\
\hline Urea & - & 0.50 & 0.50 & 0.50 & 0.50 \\
\hline Mineral Mix & - & 0.10 & 0.10 & 0.10 & 0.10 \\
\hline Salt & - & 0.10 & 0.10 & 0.10 & 0.10 \\
\hline Concentrate BC 132 & 36.63 & - & - & - & - \\
\hline Total & 100.00 & 100,00 & 100.00 & 100,00 & 100.00 \\
\hline \multicolumn{6}{|l|}{ Nutrient CF: } \\
\hline Dry matter ${ }^{1}$ & 89.36 & 89.25 & 89.23 & 88.71 & 89.53 \\
\hline Organic matter $^{1}$ & 82.46 & 82.88 & 85.28 & 83.90 & 84.21 \\
\hline Crude protein ${ }^{1}$ & 9.98 & 11.47 & 11.97 & 12.69 & 13.65 \\
\hline Crude fat $^{1}$ & 2.44 & 2.73 & 2.74 & 2.88 & 2.75 \\
\hline Crude fiber $^{1}$ & 31.92 & 26.45 & 24.57 & 24.98 & 27.59 \\
\hline BETN $^{1}$ & 38.12 & 42.23 & 46.00 & 43.35 & 40.22 \\
\hline $\mathrm{TDN}^{2}$ & 55.17 & 60.41 & 62.35 & 62.11 & 59.93 \\
\hline $\mathrm{Ca}^{1}$ & 1.53 & 0.66 & 0.84 & 0.49 & 0.72 \\
\hline $\mathrm{P}^{1}$ & 0.13 & 0.21 & 0.18 & 0.19 & 0.20 \\
\hline
\end{tabular}

${ }^{1}$ Laboratory proximate analysis result

${ }^{2}$ Calculation result (Sutardi, 2001)

Fermented ammonization rice straw was produced from urea 3\% (Musalia et al., 2000), biofad 1\% of total rice straw. Mixing material from urea and biofad were evenly spread onto rice straw. Each spread was applied for $20 \mathrm{~cm}$ height of rice straw and applied continuously up to 5-6 m height. Adequate water was also spread onto the rice straw. After those applications, rice straw was fermented for 21 days in aerobic condition. After fully fermented, the rice straw was tempered and chopped in 3$5 \mathrm{~cm}$ for CF feedstuff. The CF mixing process was carried out once in two weeks until the research finish.

Feeding amount was $3 \%$ of total live weight and offered twice a day at $7.00 \mathrm{am}$ and $2.00 \mathrm{pm}$. The observed parameters were dry matter intake (DMI), organic matter intake (OMI), crude protein intake (CPI), total digestible nutrients (TDN) intake and also digestible dry matter (DDM), digestible organic matter (DOM) and digestible crude protein (DCP).

Dry matter intake was obtained from multiplication of total $\mathrm{CF}$ offered with \% dry matter $\mathrm{CF}$ and then deduct with multiplication of discharged CF with discharged \% dry matter CF. Organic matter intake was obtained from multiplication of dry matter CF intake (g) with \% dry matter CF. Crude protein intake was obtained from multiplication of dry matter CF intake (g) with crude protein CF. Total digestible nutrients intake was obtained from multiplication of dry matter CF intake (g) with \% TDN (Tulloh, 1978; Parakkasi, 1999).

Dry matter digestibility was obtained from percentage value of different dry matter intake (g) and dry matter amount remain in fesses and divided with dry matter 
intake (g). Organic matter digestibility was obtained from percentage value of different organic matter intake $(\mathrm{g})$ and organic matter amount remain in fesses and divided with organic matter intake (g). Crude protein digestibility was obtained percentage of different crude protein intake (g) and crude protein amount remain in fesses and divided with crude protein intake (g) (Tulloh, 1978 and Parakkasi, 1999).

Data was processed using Ms. Excel 2003 (Santoso and Ashari). Data was analyzed by Costat for analysis of variance (Anova) at 95\% significance level and followed with Duncan Multiple Range Test for different significant test (Gaspersz, 1994; Gomez and Gomez, 2007).

\section{RESULT AND DISCUSSION}

Ration intake is considered as basic case to support primary needs, growth, production and reproduction (Ensminger, 1987; Sunarso, 2003; Mayulu, 2009). Based on the variance analysis, the result showed that there were no different among five treatments which agreed that ration had similar influence on DM intake. Similar DM intake showed that four CF treatments under 11, 12, 13 and 14\% CP were being consumed in similar amount with control treatment. In other words, treatments with different CP content had similar taste and palatability with control treatment. The average value of DM, OM, CP and TDN intake is shown in Table 2.

The similar palatability assumption in this research was based on similar basal utilization i.e. amofer rice straw. Based on the observation during study, cattle likes amofer rice straw due to its sour and distinctive smell. Similar DM intake was caused by similar rumen's capacity of each cattle which related to the homogenous cattle used in this study. Chemical analysis result regarding with DM intake showed no different among values i.e. 88.71$89.53 \%$ (Table 2). This could be as a factor which caused feed amount consumed by cattle showed no different. In other side, energy amount which is determined by TDN showed similar value and it was also proven by similar TDN intake.

Table 2. Average Value of DM, OM, CP and TDN intake of Simmental Cattle Offspring on Different Protein Level of $\mathrm{CF}$

\begin{tabular}{|c|c|c|c|c|c|}
\hline \multirow[t]{2}{*}{ Variable } & \multicolumn{5}{|c|}{ Treatment } \\
\hline & $\mathrm{T}_{0}$ & $\mathrm{~T}_{1}$ & $\mathrm{~T}_{2}$ & $\mathrm{~T}_{3}$ & $\mathrm{~T}_{4}$ \\
\hline & \multicolumn{5}{|c|}{........................... (kg/cattle/day) ........................... } \\
\hline Dry Matter Intake & 11.77 & 10.02 & 11.00 & 11.14 & 9.40 \\
\hline Organic Matter Intake & 9.71 & 8.30 & 9.38 & 9.35 & 7.92 \\
\hline Crude Protein Intake & 1.18 & 1.15 & 1.32 & 1.41 & 1.28 \\
\hline Total Digestible Nutrien Intake & 6.50 & 6.05 & 6.86 & 6.92 & 5.63 \\
\hline
\end{tabular}

The result of dry matter intake in control treatment and $\mathrm{CF} 11,12,13$ and 14\% crude protein were 11.77; $10.02 ; 11 ; 11,14$ and $9.4 \mathrm{~kg} /$ cattle/day, respectively has sufficient amount in fulfilling cattle needs. Dry matter intake based on cattle live weight i.e. $2.39 \%$ was in the range of cattle's dry matter intake needs. Adequate dry matter intake leads to sufficient organic matter intake that serves as a source for energy, builder substance and support the metabolic process. Statistical analysis showed that there were no significant different to the organic matter intake of Simmental cattle offspring which treated by different level of CF. The average value of organic matter intake is shown in Table 3. The result agrees with dry matter intake result due to organic matter has higher portion in dry matter ration. The value of organic matter intake for each control and CF 11, 12, 13 and 14\% crude protein treatment were $9.71 ; 8.30 ; 9.82 ; 9.35 ; 7.92$ $\mathrm{kg} /$ cattle/day, respectively. This result showed that organic matter had higher portion in dry matter intake i.e. 82.46; 82.88; 85.28; 83.90; 84.21\%, respectively. According to Tillman et al., (1998), the highest portion of organic matter substance presents in dry matter. This condition showed that dry matter has important role for cattle metabolism process.

Sufficient organic matter intake also ensures adequate VFA's rumen production which uses for maximizing rumen microbe synthesis and give positive advantage for cattle itself. In vitro analysis showed that average VFA's production for $\mathrm{T}_{0}, \mathrm{~T}_{1}, \mathrm{~T}_{2}, \mathrm{~T}_{3}$ and $\mathrm{T}_{4}$ were 90.00; 93.33; $106.67 ; 110.00$ dan $103.33 \mathrm{mM}$, respectively or range at 90.00-110.00 mM.

Based on variance analysis, crude protein intake not showed significant different among treatments. The result refused the hypothesis that different level of crude protein influence the dry matter intake. It was initially assumed that different level of crude protein in CF would give different effect on crude protein intake.

Crude protein intake could represent the adequacy amount of $\mathrm{N}-\mathrm{NH}_{3}$ for rumen microbe biosynthesis. In vitro analysis showed that ration with $11.4-13.3 \%$ crude protein and $60-80 \%$ TDN could produce $\mathrm{N}-\mathrm{NH}_{3}$ rumen $5 \mathrm{mg} \%$ which sufficient for rumen microbe to perform protein synthesis. TDN intake at different level of CF is shown in Table 3. Variance analysis showed that TDN intake in each treatment was not significantly different.

Total digestible nutrients were derived from organic material which was part from dry matter so that energy intake in TDN was also similar among treatments. TDN intake was calculated from dry matter intake of TDN so that treatments $\mathrm{T}_{1}, \mathrm{~T}_{2}, \mathrm{~T}_{3}$ and $\mathrm{T}_{4}$ which used similar TDN $\pm 62 \%$ would result in similar TDN intake. Leng et al., (1977) and Orskov (1992) stated that energy or TDN reflects utilized organic or energy amount of the body. Therefore, the adequacy of TDN associates with the availability of energy for metabolic processes.

Digestibility is defined as nutrition amount which is not excreted in fesses or assumed that nutrient contained in fesses is totally digested and absorbed. Digested amount is the difference between feed consumed with contained in fesses (France et al., 2000; DFID, 2006; Wright and Lackey, 2008). Dry matter, organic matter and crude protein digestibility of each treatment are shown in Table 3. Based on variance analysis, dry matter digestibility showed significant different $(\mathrm{P}<0.01)$. Orthogonal contrast test showed that dry matter digestibility among treatment were not significantly different among treatments. The difference of dry matter digestibility was caused by 
control treatment upon four others treatments while the four treatments itself did not show significant different. Dry matter digestibility on CF 11,12, 13 and 14\% crude protein showed significant different $(\mathrm{P}<0.01)$ compared with control treatment.

Table 3. Average value of dry matter, organic matter and crude protein digestibility of Simmental Cattle offspring on different protein level

\begin{tabular}{lccccc}
\hline Variable & \multicolumn{5}{c}{ Treatment } \\
\cline { 2 - 6 } & $\mathrm{T}_{0}$ & $\mathrm{~T}_{1}$ & $\mathrm{~T}_{2}$ & $\mathrm{~T}_{3}$ & $\mathrm{~T}_{4}$ \\
\hline & $\ldots \ldots \ldots \ldots \ldots \ldots \ldots \ldots \ldots \ldots \ldots \ldots \ldots \ldots \ldots \ldots \ldots \ldots \ldots \ldots \ldots \ldots \ldots \ldots \ldots \ldots \ldots \ldots \ldots \ldots \ldots \ldots \ldots \ldots \ldots \ldots \ldots \ldots \ldots \ldots \ldots \ldots \ldots$ \\
Digestible dry matter & $59.96^{\mathrm{b}}$ & $65.35^{\mathrm{a}}$ & $65.60^{\mathrm{a}}$ & $65.93^{\mathrm{a}}$ & $64.52^{\mathrm{a}}$ \\
Digestible organic matter & $65.18^{\mathrm{b}}$ & $70.31^{\mathrm{a}}$ & $70.54^{\mathrm{a}}$ & $70.83^{\mathrm{a}}$ & $69.06^{\mathrm{a}}$ \\
Digestible crude protein & $58.31^{\mathrm{b}}$ & $64.50^{\mathrm{a}}$ & $65.41^{\mathrm{a}}$ & $66.87^{\mathrm{a}}$ & $66.06^{\mathrm{a}}$ \\
\hline
\end{tabular}

* Different superscript on the same row shows significant different $(\mathrm{P}<0.01)$ on each treatment $\mathrm{T}_{1}, \mathrm{~T}_{2}, \mathrm{~T}_{3}, \mathrm{~T}_{4}$, compared to $\mathrm{T}_{0}$

Crude fiber content, particle size of fiber resource and higher portion of amofer rice straw in control treatment was assumed as factors which affects dry matter digestibility between $\mathrm{CF}$ and control treatment. Crude fiber content $31.92 \%$ in control treatment was higher than CF treatments i.e. 26.45, 24.57, 24.94 and 27.57\%, respectively (Table 2). Arora (1995) and Sutardi (2001) stated that higher crude fiber will decrease the digestibility performance. Crude fiber is a part of dry matter and therefore the higher crude fiber, the lower dry matter intake.

Related with particle size of fiber resource, control treatment used chopped amofer rice straw while CF treatments were not chopped. According to Table 2, it is shown that consumed amofer rice straw offered ad libitum was $63.37 \%$ compared with CF with $40 \%$.

Crystalline silica presents in the cell wall that fills the space between cells. Crystalline silica is not soluble in rumen fluid, thus a constraint to rumen microbes and enzymes to digest the produced rice straw. High content of lignin would inhibit rumen microbe to digest the rice straw, due to the aged of plant structure. The tissue has experienced lignification process which leads to develop complex bon of lignocellulose and lignohemiselulosa that is hard to digest. Cellulose, hemicelluloses and lignin, which are the major components of lignocellulosic biomass, interact with each other and form a rigid structure that increases the difficulty of degradation of lignocellulosic biomass. Despite of the biologically recalcitrant nature of lignocellulosic biomass, it can be efficiently digested by rumen microorganism in natural eco-systems. This has attracted increasing interests among the researchers worldwide. Rumen microorganism have been successfully employed to digest a variety of lignocellulosic biomass, including agricultural residues, organic fraction of the municipal solid wastes and aquatic plants (Van Soest, 1994; Barnes and Keller, 2004; Hu and Yu, 2005; Van Soest, 2006; Yue et al., 2007; Yue et al., 2013).

Similar dry matter digestibility of CF 11, 12, 13 and $14 \%$ CP were caused by similar particle size of the fiber resource. Fermented ammonization rice straw used in this treatments were initially chopped to 3-5 cm prior feeding. Chopping treatment enlarge surface area of the feed which makes it easier for rumen microbe to digest the feed. Similar particle size of the feed caused similar amount of the feed digested by rumen microbe during their activity. Rezaeian et al. (2006) showed that choping treatment enlarge the surface area of the feed that will generate rumen microbes to digest the feed easier. The similar proportion of fiber resource $(40 \%)$ in the formulation of $\mathrm{CF}$ was thought to be the factor of similar dry matter intake.

Based on variance analysis, different level of CF treatment showed significantly different $(\mathrm{P}<0.01)$ among treatments. Orthogonal contrast test results showed that organic matter digestibility of feed control significantly different with CF 11, 12, 13 and 14\% CP ( $<<0.01)$. On the other hand, organic matter digestibility was not significantly different among different level of CF treatments. The average value of organic matter and crude protein digestibility in different protein levels is shown in Table 3.

Variance analysis result showed that crude protein digestibility was significantly different due to different level of CF protein content towards Simmental cattle offspring. Orthogonal contrast test results showed that crude protein digestibility of CF 11, 12, 13 and 14\% crude protein treatment was significantly different with control treatment ( $\mathrm{P}<0.01)$. Mean while, crude protein digestibility was not significantly different among different level of protein treatment.

Sufficient concentration of $\mathrm{NH}_{3}$ to inside rumen in order to meet the needs of rumen microbial synthesis can not be separated from the use of urea in the formulation of CF. Urea is a source of NPN (Non Protein Nitrogen) that is easierchanged by rumen microbes into ammonia. Protein in rumen will be hydrolyzed by proteolitis enzyme produced in rumen microbes. Most of the rumen microbes can not directly utilize amino acids.

Crude protein digestibility with 11, 12, 13 and 14\% CP showed no difference. This was due to different percentage composition of feed ingredients in CF formulation, namely coconut and cotton seed oil cake. Coconut oil cake is one of protein source that contribute on CF protein level.

Feed source has net ammonia production rate at 2.21 $\mathrm{mM} / \mathrm{h}$ and degradation index value $62.03 \%$. It showed low protein solubility in rumen fluid was low which could be caused by the presence of substance that inhibit the change of protein into ammonia. Fat content which remains in feedstuff was thought as substance which inhibits the retrieval of amino acids and energy metabolism in the rumen microbe protoplasm. This presence caused proteolytic microbes could not perform its function which result in reducing $\mathrm{NH}_{3}$ concentrations in rumen. Gossipol cotton seed oil cake contains protein that can protect protein contained in the feed. Protected protein caused protein degradation rate by rumen microbe become slower. The higher of the protein level needs higher portion of both ration material. This was presumably that ration which had higher protein level 
would have effect on lowering the availability of ammonia for rumen microbe. Protein degradation would occur vice versa so that total protein ration derived from microbe and discharge from digestive duct would equal to digested ration protein (Ngadiyono and Baliarti, 2001; Seo et al., 2010; Habib et al., 2013) .

\section{CONCLUSIONS}

Research revealed that the use of fermented ammoniation rice straw-based CF could improve feed digestibility compared with control treatment. Based on the calculation, crude protein amount at $12 \%$ and $\pm 62 \%$ TDN was found to be the best composition level of fermented ammoniation rice straw-based CF. The use of fermented ammonization rice straw-based CF was proven could substitute fiber source obtained from forage in which their availability become lack.

\section{REFERENCES}

[1]. Arora, S.P. 1995. Ruminant Microbe Digestibility.2 $2^{\text {nd }}$ edtition Gadjah Mada University Press, Yogyakarta. (Translated by R. Murwani).

[2]. Barnes, S. P., J. Keller. 2004. Anaerobic rumen SBR for degradation of cellulosic material. Water Sci. Technol. 50 (10): 305-311.

[3]. Basuki, P. 2000. A study on growth performance of cattle farming with three level of protein and energy. Buletin Peternakan. Supplement Edition, December 2000. p. 193-203.

[4]. Cullison, A.E. and R.S. Lowrey. 1987. Feed and Feeding. $4^{\text {th }}$ Ed., Prentice Hall Inc., New Jersey.

[5]. DFID. 2006. Feed Assessment: Chemical Composition of Feeds. NR International

Managers of The Livestock Production Programme (LPP). p. 1-13.

[6]. Diwyanto, K. 2008. Utilization of local resource and technology innovation to support cattle farming development in Indonesia. Jurnal Pengembangan Inovasi Pertanian 1(3): 173-188.

[7]. Ensminger, M.C. 1987. Beef Cattle Science. $6^{\text {th }}$ Ed., The Interstate Printers and Publishers Inc., Illinois.

[8]. France, J., M. K, Theorou, R. S. Lowman and D. E. Beever. 2000. Feed Evaluation for Animal Production. In: Theodorou, M. K., J. France. Feeding Systems and Feed Evaluation Models. CABI Publishing. New York. pp. 1 - 9.

[9]. Gaspersz, V. 1994. Experimental Setup Method.2nd edition. CV. Armico. Bandung.

[10]. Gomez, K. A. and A. A. Gomez. 2007. Statistical Procedure for Agriculture Research. $2^{\text {nd }}$ edition. UI-Press. Jakarta. (Translated by E. Syamsudin and J. S. Baharsyah).

[11]. Habib, G., N. A. Khan, M. Ali and M. Bezabih. 2013. In situ ruminal crude protein degradability of by-products from cereals, oil seeds and animal origin. Livestock Science $\mathrm{x}$ : $\mathrm{xxx}-\mathrm{xxx}$.

[12]. Hadi, P. U., and N. Ilham. 2002. Problem and prospect of cattle farming development in Indonesia. J. Litbang Pertanian 21 (4): 148-157.

[13]. Hartadi, H., S. Reksohadiprodjo and A.D. Tillman. 1997. Ration composition table for Indonesia. $4^{\text {th }}$ edition, Gadjah Mada University Press, Yogyakarta.

[14]. Hu, Z. H., H. Q. Yu. 2005. Application of rumen microorganisms for enhanced anaerobic degradation of corn stover. Process Biochem. 40: 2371-2377.

Doi: http://dx.doi.org/10.1016/j.procbio.2004.09.021

[15]. Kuswandi. 2011. Local ration utilization technology to improve ruminant farming. Pengembangan Inovasi Pertanian 4 (3): 189204.

[16]. Leng, R.A., T.J. Kempton and J.V. Nolan. 1977. Nonprotein nitrogen and by pass protein in ruminant diets. AMRC Rev. 33: 1-22.

[17]. Mathius, I. W. 2008. Cattle farming development based on palm oil industry. Pengembangan Inovasi Pertanian 1(3): 206-224.

[18]. Mathius, I. W. and A. P. Sinurat. 2001. Unconventional ration material utilization for livestock. Wartazoa 11 (2): 20-31.
[19]. Mayulu, H., Sunarso, S., Sutrisno, C. I., and Sumarsono. 2012. The effects of amofer palm oil waste-based complete feed to blood profiles and liver function on local Sheep. International Journal of Science and enginering, 3 (1): 17-21.

[20]. Mayulu, H., Sunarso, C. I. Sutrisno and Sumarsono. 2010. Beef cattle development policy in Indonesia. Jurnal Litbang Pertanian 29 (1): $34-41$.

[21]. Mayulu, H., B. Suryanto, Sunarso, M. Christiyanto, F. I. Ballo and Refa'i. 2009. Feasibility of complete feed based on ammoniated fermented rice straw utilization on the beef cattle farming. J. Indon. Trop. Anim.Agric 34 (1): 74-79.

[22]. Nkrumah, J.D., E.K. Okine, G.W. Mathison, K. Schmid, C. Li, J.A Basarab, M. A. Price, Z. Wang and S.S. Moore. 2006. Relationships of feedlot feed efficiency, performance, and feeding behavior with metabolic rate, methane production, and energy partitioning in beef cattle. J. Anim. Sci. 84 (1): 145-153.

[23]. Ngadiyono, N. and E. Baliarti. 2001. Growing and production rate of male ongole cattle offspring under starbio probiotic application on their dietary treatment. J. Ilmu Pengetahuan dan Teknologi Peternakan 24 (2): 63-67.

[24]. Orskov, E.R. 1988. Protein Nutrition in Ruminants. $3^{\text {rd }}$ Ed., Academic Press, Inc., San Diego.

[25]. Parakkasi, A. 1999. Nutrition Scinces and Ruminant Feed. Penerbit Universitas Indonesia (University Press), Jakarta.

[26]. Prihartini. 1998. The effect of cotton seed oil cake (Ceiba pentandra, gaertn) toward growing ongole cattle offspring on their ration intake and digestibility. J. Ilmu Pengetahuan dan Perikanan 5 (6): 8-19.

[27]. Rezaeian, M., G.W. Beakes and A.S. Chaudhry. 2006. Effect of feeding chopped and pelleted lucerne on rumen fungal mass, fermentation profiles and in sacco degradation of barley straw in sheep. J. Anim. Feed Sci. and Technol. 128: 292-306. Doi: http://dx.doi.org/10.1016/j.anifeedsci.2005.11.004

[28]. Santosa, P. B. dan Ashari. 2005. Statistical Analysis with Microsoft Excel and SPSS. ANDI Publisher Yogyakarta, Yogyakata.

[29]. Satter, L.D. and R.E. Roffler. 1981. Influence of Nitrogen and Carbohydrate Inputs on Rumen Fermentation. (W. Haresign dan D.J.A. Cole, Ed.). Recent Developments in Ruminant Nutrition. 1st Publ., Butterworths London.

[30]. Satter, L. D. and L.L. Slyter. 1974. Effect of ammonia concentration on rumen microbial protein production in vitro. J. Nutr. 32: 199. Doi: http://dx.doi.org/10.1079/BJN19740073

[31]. Seo, J. K., J. Yang, H. J.Kim, S. D. Upadhaya, W. M. Cho and J. K. Ha. 2010. Effects of synchronization of carbohydrate and protein supply on ruminal fermentation, nitrogen metabolism an microbial protein synthesis in holstein steers. Asian -Aust. J. Anim. Sci. 23 (11): 1455-1461.

[32]. Suharto, M. 2004. Support of ration technology in cattle farming based on local resource. National Seminar of Cattle Farming. pp. 14-21.

[33]. Sunarso, L. K. Nuswantara, A. Setiadi and Budiyono. 2011. The performance of beef cattle fed by complete feed. International Journal of Engineering and Technology IJET-IJENS 11 (01): 260263.

[34]. Sunarso. 2003. Ruminant ration in agriculture livestock integration system. Professor promotion speech. Speech at Professor Formal Ceremony of Nutrient Science of Livestock in Faculty of Livestock, University of Diponegoro.Semarang, 10 September 2003. $1^{\text {st }}$ edition. Publisher of University of Diponegoro, Semarang. ISBN: 979.704.162.X.

[35]. Sutardi, T. 2001. Revitalization dairy cow through utilize ration based plantation by-product and organic mineral suplement. Penelitian RUT VIII.1. Kementerian Negara Riset dan Teknologi together with Lembaga Ilmu Pengetahuan Indonesia, Bogor.

[36]. Tillman, A. D., H. Hartadi, S. Reksohadiprodjo, S. Prawirokusumo and S. Lebdosoekojo. 1998. The Principal of Livestock Feed Science. $5^{\text {th }}$ edition, Gadjah Mada University Press, Yogyakarta.

[37]. Tulloh, N. M. 1978. Growth, Development, Body Composition Breeding and Management. In: W. A. T. Bowker, R. G. Dumsdey, J. E. Frisch, R. A. Swan and N. M. Tulloh ed., Beef cattle Management and Economics. AAUCS. Academy Press Pty Ltd, Brisbane.

[38]. Utomo, R. 2004. Review: research result on cattle's ration. Wartazoa 14 (3): 116-124. 
[39]. Van Soest, P.J. 2006. Rice straw, the role of silica and treatments to improve quality. J. Anim Feed Sci and Technol. 130: 137-171. http://dx.doi.org/10.1016/j.anifeedsci.2006.01.023

[40]. Van Soest, P. J. 1994. Nutritional Ecology of The Ruminant. 2nd Edition. Comstock Publishing Associates a Diision of Cornell University Press. Ithaca and London.

[41]. Wright, T and R. Lackey. 2008. Definitions of feed manufacturing and livestock nutrition terms. Factsheet: 1-12.
[42]. Yue, Y.B., W. W. Li and H. Q. Yu. 2013. Application of rumen microorganisms for anaerobic bioconversion of lignocellulosic biomass. Bioresource Technology 128: 738-744. Doi: http://dx.doi.org/10.1016/j.biortech.2012.11.073

[43]. Yue, Z. B., H. Q. Yu., H. Harada, Y. Y. Li. 2007. Optimization of anaerobic acidogenesis of an aquatic plant, Canna indica L., by rumen cultures. Water Res. 41: 2361-2370. Doi:

http://dx.doi.org/10.1016/j.watres.2007.02.031 